Yu. V. Honcharov ${ }^{1}$, Dr. Sc. (Econ.), Prof., orcid.org/0000-0002-3800-8038, O. Yu. Mohylevska ${ }^{2}$, Cand. Sc. (Econ.), Assoc. Prof., orcid.org/0000-0001-8482-7950,

L. V. Romanova ${ }^{3}$, Dr. Sc. (Econ.), Prof., orcid.org/0000-0003-2292-6616, O. L. Feschenko ${ }^{3}$, Cand. Sc. (Econ.), Assoc. Prof., orcid.org/0000-0002-0906-0398

\title{
INNOVATIVE CONCEPT OF THE DEVELOPMENT OF NATIONAL ECONOMY
}

Purpose. The article raises the problem of the formation of an innovative concept of the national economy development. Indeed, in the context of global imbalances and transformation of national economies, there is a need to identify vectors that will ensure the sustainability of the economic system and provide an opportunity to build a national innovative development model based on the integrated use of all possible activators.

Methodology. The methods of theoretical (conceptual) generalization, comparison, synthesis, analysis were used to reveal the general provisions and determine the basic research categories: innovation, innovative type of development, innovative development model, catching up and leading type of the development of national economy.

Findings. Highly developed countries are strengthening their dominant role through the use of new knowledge and innovation. Other countries that do not possess this knowledge and skills are dependent on them. This dependence is to pay for the benefits of civilization with cheap labor, natural resources, and other national wealth. According to the results of the study conducted, the components of the innovative concept of the national economy development are singled out. The analysis of scientific publications allowed systematizing the classification of strategies for the innovative development of national economies. The main signs of the innovation type of economic development are established. The classification of methods of state regulation of innovation activity in different countries of the world is provided. A model for evaluating the effectiveness of conducting innovation activities in a country is proposed.

Originality. The conducted scientific study made it possible to identify a list of conditions affecting the innovative concept of the development of national economy. The speed of transition to the innovative development of the economy largely depends on the state, since it is the state that can influence the processes of generating innovations and their commercialization. This made it possible to outline the transformation system and to determine support necessary for its normal functioning as well as to identify the vector that will ensure the sustainability of the economic system and will allow building a national innovative development model. Based on the proposed model for evaluating the effectiveness of innovative activities in a country, it is possible to establish which components are weaknesses or, conversely, strengths. The information obtained serves as a ground for determining the innovative concept of the development of national economy.

Practical value. The results of the study can be used by practitioners, scientists, government officials for the formation and implementation of the innovative concept of the national economy development in government programs and strategies.

Keywords: innovations, economic system, national economy, government regulation

Introduction. Constant changes, competition, the search for something new and non-standard are commonplace in the modern world. Dynamism is characteristic of all spheres of public life. The transition of the world civilization to the third millennium is accompanied by dynamism, in particular in the economic sphere. Under such conditions, those who are able to adapt more quickly to these processes have benefits in terms of development. This also applies to the institutional sphere: the sooner the state and enterprises adjust and adapt to dynamically changing conditions, the more they contribute to their development.

Innovations in a national economy are key concepts of development. This is proved by the world practice, which shows that economic actors that are able to in-

(C) Honcharov Yu. V., Mohylevska O. Yu., Romanova L. V., Feschenko O. L., 2019 novate show higher rates of economic growth. At the level of national economy, this manifests itself in higher rates of GDP growth, the improvement of the quality of the socio-economic life of the population, and so on. In a globalized world, they are increasingly trying to create their own system of actions that will foster the emergence and spread of innovation [1]. Countries are developing adaptation mechanisms that can ensure the viability and competitiveness of their own national economic systems. The most effective tool in this process is the transition to an innovative model for the development of national economy, which is envisaged by the development of a national strategy for national development.

Analysis of the recent research and publications. Issues of the theory and practice of innovative development of national economies are considered in scientific works of leading contemporary scholars who have become clas- 
sics of economic thought, among whom one can in the first place mention P. Drucker, S. J. Grossman, R. Zeiler, F. Ibbotson, P. Krugman, F. Poszolo, P. Romer, B. Santo, A. Smith, R. Tucker, S. Fischer, E. Helpman, P. Houvitt, M. Huchek, J.Schumpeter. Domestic scientists have also worked quite well on these issues, in particular: O.Amosha, Y. Bazhal, L. Vorotina, A. Galchynskyi, V. Heyets, M. Yermoshenko, S. Yerokhin, S. Illyashenko, T. Kovalchuk, N.Chukhrai, I. Shtuler, L. Yakovenko, M. Holovatyi and others.

Unsolved aspects of the problem. An analysis of the scientific views of the aforementioned scholars suggests that the issue of the development of national economies can be viewed from different positions; for example, depending on the innovative development of the sectors of an economy, or depending on the innovative development of a national economy as a holistic complex, or depending on the innovation development determined by a transnational corporation. That is, the problems of the importance of supranational, regional, and branch systems of innovation are considered from different positions. But in the new context, due to the globalization impact, macroeconomic approaches in defining an innovative concept for the development of national economy need detailed attention. It is important that all economists agree that at the macroeconomic level, the innovation path of the development of national economies depends decisively on their historical development and the state of the economy. In this regard, research related to the study of the state and the improvement of the existing concepts and peculiarities of the formation and development of national innovation systems is relevant. Further research is also needed on the possibility of adapting certain elements of concepts of national economic development from the experience of European countries, which determines the necessity and need to take into account national interests.

The objective of the article is to study the development of national economy on the basis of the use of the innovative concept as a stimulating developmental activator.

Description of the methodology of the study. In the process of writing the article, the methods of theoretical (conceptual) synthesis, comparison, synthesis, and analysis were used - to explain the general concepts and to define the basic categories of the research: innovations, the innovative type of development, the innovative development model, the catching up and leading type of the development of national economy.

Main results of the study. The innovative development model is the key mechanism where the systemforming role in the development of national economy belongs to innovation. The basis of modern interpretation of innovations is the dynamic changes in the surrounding economic, political, natural, and ecologic environment, and the main function of innovation in the macroeconomic approach is just the function of change, transition, transformation, and regeneration.

The innovative development of economy is derived from innovation, the former being treated by most scholars as a way of economic growth based on innova- tion. In this case, there are several conceptual conditions; in particular, innovations should be aimed at improving the economic activity of the national system, involve the use of resource factors in the creation of innovative products and the formation of competitive advantages.

Oddly enough, innovation is not a discovery of the XXI century. On the contrary, innovation was present throughout the period of existence of mankind. What else explains the fact that the emergence and implementation of novelties, inventions, know-how's, the implementation of innovation in engineering and technology accompany the whole history of mankind, contributing to the growth of labor productivity and the global economy as a whole? The main feature of the modern innovation system that sets it apart from the previous ones is only the speed of their implementation.

The development of world civilization suggests that the phenomenon of "innovation" is considered as a paradigm of national development. Accordingly, by the innovative type of development of national economy one generally means the process of social production, the key characteristic of which is the use of accumulated knowledge and its transformation into innovation. And only afterwards, innovations form the basis for the growth of national economy with an appropriate adaptation to dynamically changing conditions. This process, provided that it is initiated in the strategy of economic growth, involves updating the engineering and technology bases of production, which is related to the reduction of energy and resource intensity, the reduction of the burden on the environment, the growth of labor productivity, the comprehensive development of personality abilities, an increase in motivation for performing creative (including scientific) activities, processes of democratization in society, and others.

The innovative concept for the development of national economy can be implemented through a developed system of relations and institutions that create the necessary conditions for the implementation of scientific and technological progress within the framework of a defined national strategy of national development [2].

From the standpoint of macroeconomic regulation, the innovative concept of the development of a national economy should be considered as a concept that contains a set of identified socio-economic priorities, tools, and mechanisms, criteria and indicators of innovation and economic development. The innovative concept of the development of national economy is the foundation of the national innovation policy, the priority of which is orientation towards the development of education, science, research and development, intellectualization of society, and others.

From the structural point of view, the innovative concept of the development of national economy is a set of sectors and branches of the economy that are directly involved in the innovation process, and of institutional support at the national level. On the basis of generalizations of scientific research, five components of the innovative concept of the development of national economy can be singled out (Fig. 1). 


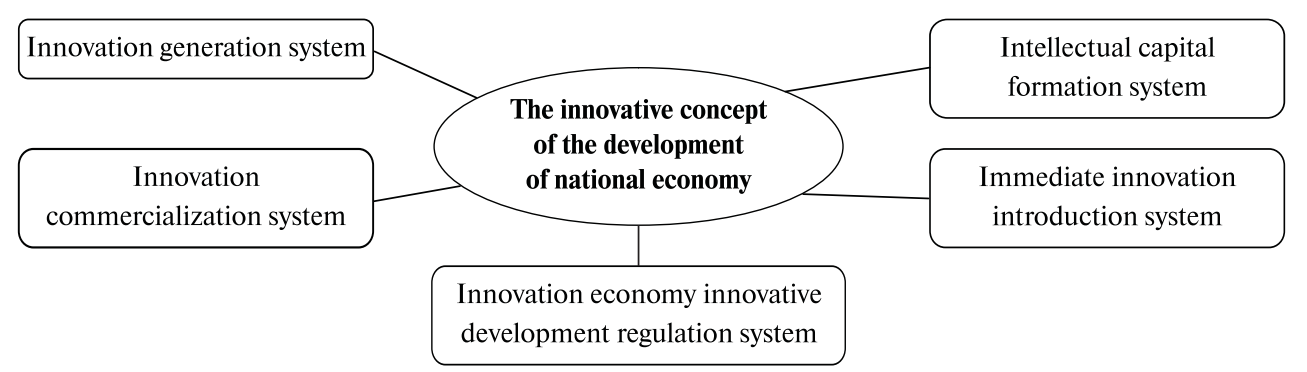

Fig. 1. Components of the innovative concept of the development of national economy

Dynamic processes associated with transformation of strategic priorities promote the formation of an economic environment that is maximally oriented to the use and commercialization of innovations. Thus, the transition to the innovative development of national economy is associated with the modification of innovation priorities in the real sector of the economy, the growth of the level of intellectualization of society and, thirdly, the creation of business centers (clusters) that commercialize innovation.

Macroeconomic possibilities of the transition of national economies to the policy of innovative type of development are determined by the choice of strategy and concept. An analysis of scientific publications made it possible to systematize the classification of strategies for the innovative development of national economies (Fig. 2).

Quite often, the innovative type of development is treated as investments that stimulate the process of transforming knowledge into competitive products, of transforming scientific research costs into economic profit. It is a question of the fact that, in the context of this type of development, innovation is transformed from an indicator into a paradigm of development, thereby contributing to the transformation of the existing in society way of thinking, worldview, values, motivation and, most importantly, system of management of economic activities of all economic subjects without distinction. Activator of innovation arises at the junction of three areas: the natural one, the organized one, and the heuristic one. Thus, activator of innovation is a process, an information carrier, and a group of people with knowledge about the needs and prospects of future benefits and the benefits of operating innovations that will lead to the growth of national economies [3].

The main prerequisites that have contributed to the transition to the innovative type of development of national economies are the following factors:

- change of principles of competition and mechanisms of obtaining competitive advantages;

- the deepening of the shortage of natural resources and the intensifying of the struggle for limited raw materials, which contributed to the transformation of the paradigm of their use;

- growth of the needs of society along with the strengthening of requirements for economic processes (especially environmental ones);

- aggravation of energy, raw materials, social, industrial, and other problems;
- the increasing role of scientific and technological progress in ensuring economic development;

- psychological awareness of the benefits of introducing innovations;

- increase in profitability norm in the production and sales of innovative products; increase in profitability of innovation activity in general [4].

In Fig. 3, the innovation cycle of the emergence of the activator of the innovation development of national economy, which is proposed by domestic scientists, is presented.

In our opinion, the main signs of the innovative type of economic development are:

- high level of education and science development. Personality and professional development of a person is the most important prerequisite for modernization, which "promotes the very rapid modernization of societies, serves as the basis for the development of knowledgeintensive industries, the introduction of advanced technologies into economic practice" [5]. An increase in the number of specialists in the field of scientific research contributes to solving important social problems: unemployment, raw material orientation of the domestic economy, energy dependence, social tension, and others;

- production of new knowledge. Knowledge is the power that is needed to accelerate historical progress. In order to "survive", a person must master the knowledge that is necessary for the profession;

- development of education. Education is increasingly integrated into the market economy model and is becoming one of the key elements of the service market. Innovations are formed mainly in those areas and fields that are capable of generating benefits that are measured in terms of monetary equivalents or some economic effect;

- introduction of resource-saving technologies. Modern resource-saving innovations contribute to saving resources, which leads to higher incomes;

- reduction of the time lag between the implementation of a scientific discovery and its commercialization. Scientific research is mainly of cognitive nature and is purposefully aimed at addressing the basic problems and needs that ensure the functioning of enterprises;

- combination of science and production. Making scientific discoveries and their commercialization has become possible due to the combination of two previously separated branches: production and science. At large enterprises, research departments are created, which, while focusing on the market, carry out scientific re- 
STRATEGIES OF THE INNOVATIVE DEVELOPMENT OF NATIONAL ECONOMIES

\author{
According to development catalyst
}

diffusion of innovations - the top-priority initiative on the part of all economic entities of different

levels (except the state) in the sphere of diffusion of innovations in society and economy

state support for innovative firms - the role of the bearer and key conductor of innovation

processes in society belongs to the state

\title{
According to coverage
}

local innovation environment - it is based on the stimulation of the development of local

innovation centers: technoparks, technopolises, business incubators, etc.

inter-branch scientific and technical complexes and clusters - they are associated

with the promotion of the development of innovation clusters, zones, regions

international innovation and technology cooperation - it is based on the development of cooperation

systems of domestic and foreign innovation, scientific research structures and production systems

According to the origin of innovative ideas

Strategy of transference, of imitating development

Strategy of borrowing

Pioneering (self-development) strategy

According to the origin of innovative ideas

local advantage strategy - focusing on individual priorities of innovative development

strategy of balanced innovation development - it is based on the innovation approach in all sectors and regions of the economy

Fig. 2. Classification of strategies for the innovative development of national economies

search. For example, the creation of such innovations as the plane, the camera, the cinema, etc. was possible due to many years of scientific research and coincidence of knowledge from various fields: physics, chemistry, mechanics, others. However, large companies, with their R\&D departments, have significantly accelerated scientific research in these areas, being motivated to obtain significant commercial benefits. The formation of this feature came with understanding that "access to markets with a new product gives an opportunity to receive 20-50\% more profit" [6]. Thus, among the mechanisms of entrepreneurship, "rent search" through innovations is in the first place;

- increased intellectualization of production and growth of the role of intellectual capital. In the structure of property of a company, there is an increase in the share of intellectual and intangible assets. The cost of a brand, as an intangible asset, increases. Countries that adhere to the innovative development model are increasingly focusing on intellectual capital and trying to increase its share in the total value of enterprises. In Europe, this indicator is $50-68 \%$, and in Ukraine $-1 \%$.

Among other signs of the innovation model of the development of national economy, the following ones can be singled out:

- high level of innovation activity of enterprises;

- outstripping growth rates among all employed people of such categories of workers as researchers, theorists, engineers, developers of new technologies and equipment;

- significant volumes of spending on science and innovation; 


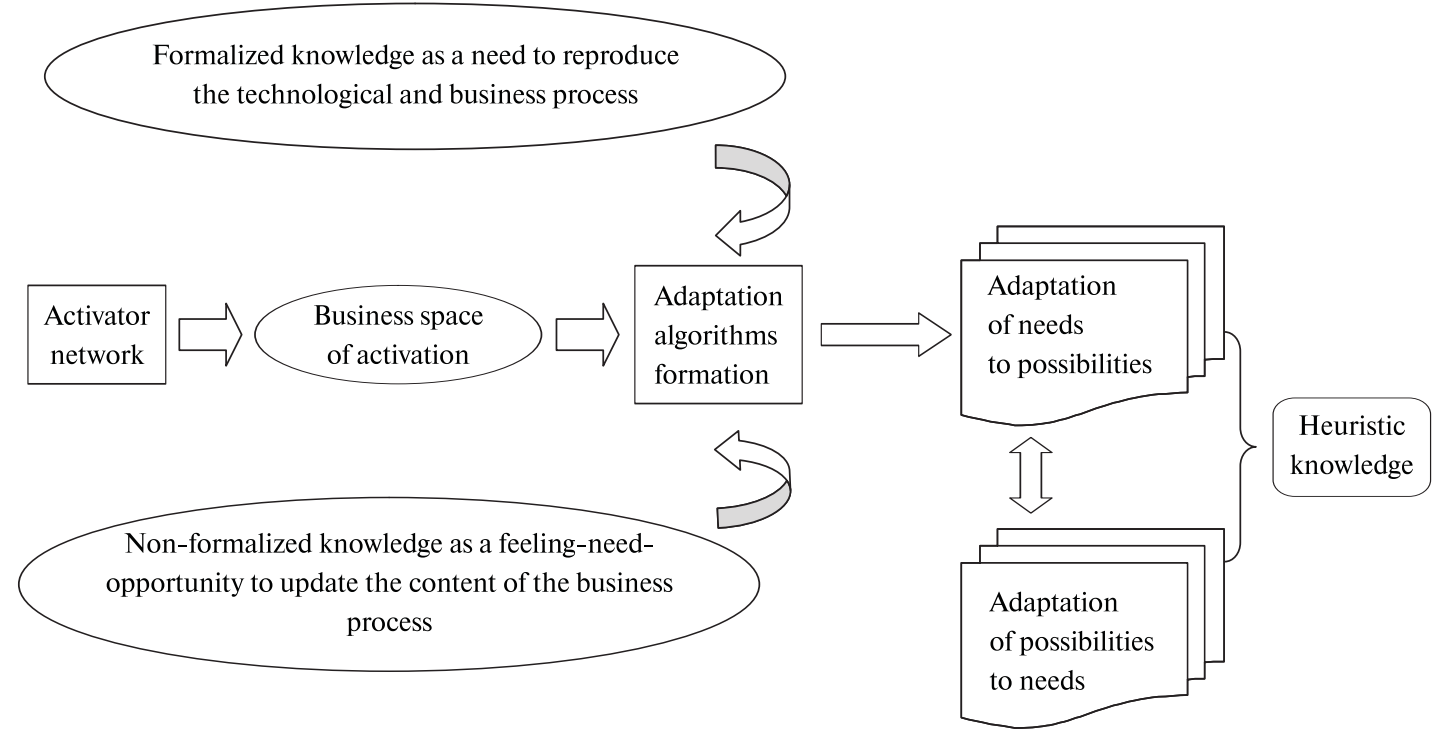

Fig. 3. Innovation cycle of the emergence of the activator of the innovative development of national economy [4]

- wide informatization of society;

- the predominance of labor of intellectual nature over that of industrial one;

- growing requirements for the level of qualification of employees;

- an outstripping increase in the proportion of the science-intensive sector of production in the sectoral structure of a country;

- an increase in the share of products with high added value;

- low profitability of production of standardized products.

The transition to the innovative type of development is inextricably linked with state regulation of innovation activity. In different countries of the world, it occurs through various methods and means. Table 1 lists a classification of the methods of state regulation of innovation activity in different countries of the world.

In order to assess the effectiveness of conducting the innovation activities of a country, it is advisable to calculate its integral indicator. In order to determine the effectiveness of a country's innovation activities taking into account the peculiarities of the innovation process, it is necessary to use the assessment of key indicators that characterize the scientific and technical, industrial, technical and technological, and productive components. For such an assessment, it is necessary to analyze at least twelve indicators. Indicators and formulas that fully define the effectiveness of conducting innovation activities of a country are given in Table 2.

Since all the recommended assessment indicators are dimensional in terms of components, they should be normalized in order to bring them into a range from 0 to 1 . The closer a normalized indicator is to zero, the worse it is. It is then necessary to determine the weighting factor both for each indicator $\left(a_{1}, a_{2}, \ldots, a_{12}\right)$ and the total weight of the individual components based on the expert estimation method. Such factors make it possible to generalize each component for a more precise defini- tion of the integral value of the effectiveness of innovation development on the basis of the calculation of the arithmetic mean weighted value

$$
G I_{i j}=\frac{\sum_{i=1}^{n} X_{i} \cdot a_{i}}{\sum_{i=1}^{n} a_{i}},
$$

where $G I_{i j}$ is a general indicator (integral) of the assessment of the corresponding component; $X_{i}$ are coefficients that characterize the corresponding component; $a_{i}$ are weighting factors of the $i^{\text {th }}$ indicator of each component.

Thus, the integral indicator of the effectiveness of innovation activity of a country is determined by the formula

$$
I I_{I A}=\frac{G I_{S T} \cdot W_{S T}+G I_{P} \cdot W_{P}+G I_{E T} \cdot W_{E T}+G L_{E} \cdot W_{E}}{W_{S T}+W_{P}+W_{E T}+W_{E}},
$$

where $I I_{I A}$ is an integral indicator of the effectiveness of innovation activity of a country; $G I_{S T}$ are generalizing indicators of the assessment of the scientific and technical component; $G I_{P}$ are generalizing indicators of the calculation of the production component; $G I_{E T}$ are generalizing indicators the assessment of the engineering and technology component; $G I_{E}$ are generalizing indicators of the assessment of the effective component; $W_{S T}$ are the weighting factors of the scientific and technical component; $W_{P}$ are the weighting factors of the calculation of the production component; $W_{E T}$ are the weighting factors of the engineering and technology component; $W_{E}$ are the weighting factors of the effective component.

To interpret the value of the level of effectiveness of conducting innovation activities in Ukraine obtained as a result of applying the proposed methodology, it is recommended to use a graded system that includes four levels: high, medium, low, and critical ones (Table 3). 
Classification of methods of state regulation of innovation activity in different countries of the world [7]

\begin{tabular}{|c|c|c|}
\hline Method & Means of influence & Country \\
\hline \multirow{2}{*}{$\begin{array}{l}\text { Economic } \\
\text { and legal }\end{array}$} & Stimulating the innovation of small business & USA \\
\hline & $\begin{array}{l}\text { Laws on patents, trademarks, copyright, preferential loans, compulsory } \\
\text { licensing technologies, on promotion of investments in venture business, on } \\
\text { technological innovations, on innovation }\end{array}$ & $\begin{array}{l}\text { USA, France, United } \\
\text { Kingdom, Japan }\end{array}$ \\
\hline \multirow{3}{*}{$\begin{array}{l}\text { Financial } \\
\text { support }\end{array}$} & Budgetary financing fundamental research & \multirow{2}{*}{$\begin{array}{l}\text { USA, France, Japan, United } \\
\text { Kingdom, Germany, Sweden, } \\
\text { Switzerland, South Korea, } \\
\text { Netherlands, Italy, Canada }\end{array}$} \\
\hline & $\begin{array}{l}\text { Program-targeted financing: through participation in international, state, and } \\
\text { regional programs }\end{array}$ & \\
\hline & $\begin{array}{l}\text { State scientific and technical programs: plan tasks for state institutions; government } \\
\text { contracts to private research and design organizations; forecasts of development of } \\
\text { scientific research and design work in the private sector of the economy }\end{array}$ & $\begin{array}{l}\text { USA, Japan, France, United } \\
\text { Kingdom, Germany, } \\
\text { Canada }\end{array}$ \\
\hline $\begin{array}{l}\text { Contract } \\
\text { system of } \\
\text { relations }\end{array}$ & $\begin{array}{l}\text { State research contract: the client is the government; the contractor is a firm, a } \\
\text { scientific center, a university }\end{array}$ & USA \\
\hline $\begin{array}{l}\text { Stimulation } \\
\text { of R \& D }\end{array}$ & $\begin{array}{l}\text { Subsidies: are provided by individual research projects to their immediate } \\
\text { executors - scientists, engineers, inventors, and not to the institutions where } \\
\text { they work; are provided to representatives of the private sector }\end{array}$ & USA \\
\hline Tax policy & $\begin{array}{l}\text { Preferential tax treatment: differentiated system of tax privileges; preferential } \\
\text { loans }\end{array}$ & $\begin{array}{l}\text { USA, Japan, France, } \\
\text { Canada, United Kingdom, } \\
\text { France, Germany }\end{array}$ \\
\hline Credit policy & Preferential crediting of innovations; lending for innovations by banks & USA \\
\hline $\begin{array}{l}\text { Government } \\
\text { procurement }\end{array}$ & $\begin{array}{l}\text { Purchase of innovation projects development: tenders for the best project of } \\
\text { public buildings }\end{array}$ & France, Germany \\
\hline $\begin{array}{l}\text { Development } \\
\text { of innovation } \\
\text { infrastructure }\end{array}$ & $\begin{array}{l}\text { Business incubators, innovation centers: technoparks; business parks, } \\
\text { industrial parks; technopolises }\end{array}$ & $\begin{array}{l}\text { USA, France, Belgium, } \\
\text { Israel }\end{array}$ \\
\hline $\begin{array}{l}\text { Attraction of } \\
\text { foreign } \\
\text { capital }\end{array}$ & $\begin{array}{l}\text { Creation of enterprises with foreign investments; granting subsidies (grants) for } \\
\text { innovative activities to scientific institutions, higher education institutions, } \\
\text { scientific specialists }\end{array}$ & USA \\
\hline
\end{tabular}

Such a model for assessing the effectiveness of a country's innovation activity helps to determine which components are weaknesses or, conversely, strengths. The information obtained serves as a catalyst for the definition of the innovative concept of the development of national economy. From this, it follows that the innovative concept of the development of national economy is possible under the following conditions:

- transformation of innovation from a strategy to a paradigm of development both in scientific and ideological practice;

- understanding innovation not as a temporary, onetime tool for improving quality and accelerating growth, but rather as a continuous process of updating and bringing to conformity with the civilization standards the quality of the development of a state, a region or society as a whole;

- complementing economic processes with a coordinated, one-way, and, at the same time, joint participation and support of society and state authorities;

- maximum use of available educational and scientific potential;

- transformation of innovations into an integrated, universal, and comprehensive development strategy with an emphasis on technological and economic trans- formation supplemented by the updating of the sociopolitical, legal, cultural, and institutional spheres of society, and others [8].

Conclusions and recommendations for further research. Thus, the innovative model of the development of national economy is not only high innovation activity of enterprises, the development of high-tech industries, increased costs for and investments in education and science, but also the achievement of high human development and constant growth of the intellectual potential of the state. This is reflected in an increase in the level of education of the population, specialists in the field of research, the use of science in everyday life.

The development of the innovative concept of the development of national economy is an objective necessity, since it can:

- accelerate the rates of productivity growth of factors of production;

- ensure acceleration of economic growth and socioeconomic development;

- accelerate structural shifts;

- promote redistribution of resources;

- improve the quality of life standards;

- improve the country's status in the global economy; 
Indicators of the components of a state's innovation activities, which determine its effectiveness

\begin{tabular}{|c|c|c|}
\hline № & Indicator & Formula of calculation \\
\hline 1. & $\begin{array}{l}\text { The rate of costs for conducting } \\
\text { research and development works }\end{array}$ & $\begin{array}{l}C_{\mathrm{R} \& \mathrm{D}}=A_{\mathrm{R} \& \mathrm{D}} / N \text {, where } A_{\mathrm{R} \& \mathrm{D}}-\text { annual costs for } \mathrm{R} \& \mathrm{D} \text {, thousand } \mathrm{UAH} ; N-\text { the } \\
\text { number of R \& D performers, persons }\end{array}$ \\
\hline 2. & $\begin{array}{l}\text { The share of technology } \\
\text { development }\end{array}$ & $\begin{array}{l}S_{T D}=C_{T D} / \sum C_{T E C H N}, \text { where } C_{T D}-\text { costs for technology development, thousand } \\
\mathrm{UAH} ; \sum C_{T E C H N}-\text { the total amount of costs for technology, thousand UAH }\end{array}$ \\
\hline 3. & $\begin{array}{l}\text { The rate of utilization of } \\
\text { scientific personnel potential }\end{array}$ & $\begin{array}{l}R_{S P P}=N_{R D W} / N_{S W}, \text { where } N_{R D W}-\text { the number of workers employed in R \& D, } \\
\text { thousand persons; } N_{S W}-\text { the number of scientific personnel, thousand persons }\end{array}$ \\
\hline 4. & $\begin{array}{l}\text { The rate of creation and } \\
\text { introduction of innovative } \\
\text { products }\end{array}$ & $\begin{array}{l}R_{C I I P}=\left(\sum N_{C I P}+\sum N_{I I P}\right) / N_{E}, \text { where } N_{C I P}-\text { the number of created innovative } \\
\text { products, thousand units; } N_{I I P}-\text { the number of introduced innovative products, } \\
\text { thousand units; } N_{E}-\text { a total number of enterprises, thousand units }\end{array}$ \\
\hline 5. & $\begin{array}{l}\text { The rate of innovation } \\
\text { implementation }\end{array}$ & $\begin{array}{l}R_{I I P}=A_{I I P} / N_{E}, \text { where } A_{I I P}-\text { annual costs for the implementation of innovations } \\
\text { (including costs for the purchase of technologies and new products), thousand UAH; } \\
N_{E}-\text { the total number of enterprises, thousand units }\end{array}$ \\
\hline 6. & $\begin{array}{l}\text { The share of exports of innovative } \\
\text { products in the total volume of } \\
\text { commodity output }\end{array}$ & $\begin{array}{l}S_{E X P}=I P_{E X} / \sum C_{O}, \text { where } I P_{E X}-\text { volume of export of innovative products, thousand } \\
\text { UAH; } \sum^{\text {- total volume of commodity output, thousand UAH }}\end{array}$ \\
\hline 7. & $\begin{array}{l}\text { The specific quantity of new } \\
\text { technologies and products } \\
\text { developed }\end{array}$ & $\begin{array}{l}N_{D}=Q_{A} / N_{S P}, \text { where } Q_{A}-\text { annual quantity of new technology/products developed } \\
\text { within the framework of performing R\& } \mathrm{D} \text {, units; } N_{S P}-\text { the number of scientific } \\
\text { personnel, thousand persons }\end{array}$ \\
\hline 8. & $\begin{array}{l}\text { Labor productivity in the } \\
\text { creation of innovations }\end{array}$ & $\begin{array}{l}P_{I N}=V_{I P} / N_{I P}, \text { where } V_{I P}-\text { volume of innovative products, thousand } \mathrm{UAH} ; N_{I P}-\text { the } \\
\text { number of persons employed in the creation of innovative products, thousand persons }\end{array}$ \\
\hline 9. & $\begin{array}{l}\text { The rate of productivity of } \\
\text { information in the creation of } \\
\text { innovations }\end{array}$ & $\begin{array}{l}R_{I C I}=S_{I M} / R_{I M}, \text { where } S_{I M}-\text { share of using information materials in the process of } \\
\text { creating innovation, } \% ; R_{I M} \text { - average remainder of the share of information } \\
\text { materials, units }\end{array}$ \\
\hline 10. & $\begin{array}{l}\text { The rate of effectiveness of } \\
\text { innovation activities }\end{array}$ & $\begin{array}{l}R_{E F}=P_{I P} / I_{I A}, P_{I P}-\text { profit from the sale of innovative products, thousand } \mathrm{UAH} ; \\
I_{I A}-\text { volume of investments in innovation activity, thousand UAH }\end{array}$ \\
\hline 11. & $\begin{array}{l}\text { Profitability of creation and } \\
\text { commercialization of innovative } \\
\text { products }\end{array}$ & $\begin{array}{l}P_{I P}=\left(N P_{I P} / C_{I P}\right) * 100 \%, N P_{I P}-\text { net profit from the sales of innovative products } \\
\text { thousand UAH; } C_{I P}-\text { cost of production of innovative products, thousand UAH }\end{array}$ \\
\hline 12. & $\begin{array}{l}\text { The rate of growth of the volume } \\
\text { of innovative products }\end{array}$ & $\begin{array}{l}R_{G}=V_{I P R} / V_{I P B}, V_{I P R}-\text { volume of the sales of innovative products for the reporting } \\
\text { period, thousand UAH; } V_{I P B}-\text { volume of the sales of innovative products in the base } \\
\text { period, thousand UAH }\end{array}$ \\
\hline
\end{tabular}

Table 3

Interpretation of the results of the integral indicator of the assessment of the effectiveness of innovation activity of a country

\begin{tabular}{|c|l|c|}
\hline № & $\begin{array}{c}\text { Level of effectiveness of } \\
\text { innovation activities }\end{array}$ & $\begin{array}{c}\text { Value of the } \\
\text { integral indicator }\end{array}$ \\
\hline 1. & High & $(0.75-1]$ \\
\hline 2. & Medium & $(0.51-0.74]$ \\
\hline 3. & Low & $(0.25-0.5]$ \\
\hline 4. & Critical & {$[0-0.24]$} \\
\hline
\end{tabular}

- strengthen the national competitiveness, and others [9].

The pace of transition to the innovative development of economy depends to a large extent on the state, because it is a state that is capable of influencing the processes of generating innovations and their commercialization. At the same time, the state is the main subject that is responsible for the innovative offer, finances fun- damental research and development, regulates innovation activity, the educational and scientific processes, which influences the development of innovation infrastructure, stimulates processes of stimulating innovation, etc. [10].

Thus, the innovative concept of the development of national economy is the latest paradigm of transformation in society, which involves the active use of information (knowledge), followed by their transformation into innovation. The innovative concept of the development of national economy is directly related to the modernization and transformation of the existing structures of branches of economy, thereby contributing to improving the competitiveness and intellectual potential of the national economy.

\section{References.}

1. Geets, V., 2012. On the unity and contradictions in the development of society, state and economics. Ukraine economy [online], 11, pp. 4-22. Available at: <http://nbuv.gov.ua/UJRN/EkUk_2012_11_2> [Accessed 14 November 2017]. 
2. Marchenko, O., 2012. National Innovation System as an Integrator of Knowledge. Visnyk Natsionalnoii Yurydychnoii Akademii Ukrainy imeni Yaroslava Mudroho [online], 2, pp. 24-34. Available at: <http://dspace.nlu. edu.ua/handle/123456789/3494> [Accessed 27 February 2018].

3. Shtuler, I. Y., 2015. Innovative approach to determining integrated marketing communications to ensure development of national forest complex. In: Larina, Y.S. and Romanenko, J.J., eds., 2015. A new role of marketing and communication technologies in business and society: local and global aspects: [collective monograph.] St. Louis, Missouri, USA: Publishing House Science and Innovation Center, Ltd.

4. Shtuler, I., Cherlenyak, I., Domyshche-Medyanik, A. and Voitovych, S., 2017. Conditions of formations and stimulation of the activators of innovative development of Ukraine. Problems and Perspectives in Management (PPM), 15(4), pp. 150-160. DOI: 10.21511/ppm.15(4).2017.13.

5. Gurovskaya, T., 2011. Political rent as the central problem of the new political economy. Formation of $a$ market economy [online], pp. 185-192. Available at: <http://ir.kneu.edu.ua/handle/2010/1418> [Accessed 9 January 2018].

6. Kindzersky, Yu., 2013. Industry of Ukraine: strategy and policy of structural and technological modernization.

7. Datsiy, O., 2010. Innovative model of economic development of Ukraine in the conditions of globalization: Monograph [online]. Available at: <http://www.nas.gov. ua/UA/Book/Pages/default.aspx? BookID= 0000004712> [Accessed 9 January 2018].

8. Sedlyar, M., 2012. Interconnection of knowledge and innovations in the modern economy. Scientific journal of the National Academy of Sciences of Ukraine. MP Drahomanov Economics and Law, 18, pp. 61-67.

9. Vovkanych, S. and Shults, S., 2011. Modernization of Economics and Society: Axiological, Socio-Humanistic, and Intellectual-Innovative Contexts. Logistics [pdf], pp. 15-30. Available at: <http://ena.lp.edu.ua/ bitstream/ntb/12287/1/004_Modern\%D1\%96zac\% D1\%96ja\%20ekonom\%D1\%96ki_15_30_706.pdf> [Accessed 22 December 2017].

10. Holovatyi, M., 2015. The state and society: The conceptual foundations and social interaction in the context of formation and functioning of states. Economic Annals-XXI, 9-10, pp. 4-8.

\section{Інноваційний концепт розвитку національної економіки}

\section{Ю. В. Гончаров ${ }^{1}$, О. Ю. Могилевська ${ }^{2}$, Л. В. Романова ${ }^{3}$, О. Л. Фешенко ${ }^{3}$}

1 - Міжнародний економіко-гуманітарний університет імені академіка Степана Дем'янчука, м. Київ, Україна, e-mail: goncharov_yv@ukr.net

2 - Київський міжнародний університет, м. Київ, Україна, e-mail: olgaym1993@gmail.com

3 - Міжрегіональна академія управління персоналом, м. Київ, Україна, e-mail: romanovalida@ukr.net; elf-imef@ ukr.net
Мета. У роботі порушуються проблеми формування інноваційного концепту розвитку національної економіки. В умовах глобальної диспропорційності та трансформаційності національних економік виникає потреба виявлення векторів, що забезпечать стійкість економічної системи та нададуть змогу вибудувати національну інноваційну модель розвитку на основі комплексного використання усіх можливих активаторів.

Методика. Застосовувалися методи теоретичного (концептуального) узагальнення, порівняння, синтезу, аналізу - для розкриття загальних положень і визначення базових категорій дослідження: інновації, інноваційний тип розвитку, інноваційна модель розвитку, навздогінний та випереджаючий тип розвитку національної економіки.

Результати. Високорозвинені країни посилюють свою домінуючу роль за рахунок використання новітніх знань і впровадження інновацій. Інші країни, що не володіють цими знаннями та вміннями, потрапляють до них у залежність. Ця залежність полягає у розрахунку за блага цивілізації дешевою робочою силою, природними ресурсами та іншим національним багатством. За результатами проведеного дослідження виділені складові інноваційного концепту розвитку національної економіки. Аналіз наукових публікацій дав змогу систематизувати класифікацію стратегій інноваційного розвитку національних економік. Встановлені головні ознаки інноваційного типу розвитку економіки. Представлена класифікація методів державного регулювання інноваційної діяльності в різних країнах світу. Запропонована модель оцінювання ефективності ведення інноваційної діяльності країни.

Наукова новизна. Проведене наукове дослідження дало змогу виявити перелік умов, що впливають на інноваційний концепт розвитку національної економіки. Швидкість переходу до інноваційного розвитку економіки у значній мірі залежить від держави, оскільки саме вона здатна вплинути на процеси генерування інновацій та їх комерціалізаціï. Це дало змогу окреслити систему трансформації та визначити необхідне для іiї нормального функціонування забезпечення. А також виявити вектор, що забезпечить стійкість економічної системи й надасть змогу вибудувати національну інноваційну модель розвитку. На основі запропонованої моделі оцінювання ефективності інноваційної діяльності країни можна встановити, які саме складові є слабким чи, навпаки, сильним місцем. Отримана інформація слугує основою для визначення інноваційного концепту розвитку національної економіки.

Практична значимість. Результати дослідження можуть бути використані практиками, науковцями, представниками влади для формування й реалізації інноваційного концепту розвитку національної економіки в державних програмах і стратегіях.

Ключові слова: інновації, економічна система, національна економіка, державне регулювання 


\section{Инновационный концепт развития национальной экономики}

\section{Ю. В. Гончаров ${ }^{1}$, О. Ю. Могилевская ${ }^{2}$, Л. В. Романова ${ }^{3}$, О. Л. Фещенко ${ }^{3}$}

1 - Международный экономико-гуманитарный университет имени академика Степана Демьянчука, г. Киев, Украина, e-mail: goncharov_yv@ukr.net

2 - Киевский международный университет, г. Киев, Украина, e-mail: olgaym1993@gmail.com

3 - Межрегиональная академия управления персоналом, г. Киев, Украина, e-mail: romanovalida@ukr.net; elf-imef@ ukr.net

Цель. В работе поднимаются проблемы формирования инновационного концепта развития национальной экономики. Ведь в условиях глобальных диспропорций и трансформированности национальных экономик возникает потребность выявления векторов, которые обеспечат устойчивость экономической системы и предоставят возможность выстроить национальную инновационную модель развития на основе комплексного использования всех возможных активаторов.

Методика. Применялись методы теоретического (концептуального) обобщения, сравнения, синтеза, анализа - для раскрытия общих положений и определения базовых категорий исследования: инновации, инновационный тип развития, инновационная модель развития, догоняющий и опережающий тип развития национальной экономики.

Результаты. Высокоразвитые страны усиливают свою доминирующую роль за счет использования новых знаний и внедрения инноваций. Другие страны, которые не обладают этими знаниями и умениями, попадают к ним в зависимость. Эта зависимость заключается в оплате за блага цивилизации дешевой рабочей силой, природными ресурсами и другими национальными богатствами. По результатам проведенного исследования выделены составляющие инновационного концепта развития национальной экономики. Анализ научных публи- каций позволил систематизировать классификацию стратегий инновационного развития национальных экономик. Установлены главные признаки инновационного типа развития экономики. Представлена классификация методов государственного регулирования инновационной деятельности в разных странах мира. Предложена модель оценки эффективности ведения инновационной деятельности страны.

Научная новизна. Проведенное научное исследование дало возможность выявить перечень условий, влияющих на инновационный концепт развития национальной экономики. Скорость перехода к инновационному развитию экономики в значительной степени зависит от государства, поскольку именно оно способно повлиять на процессы генерирования инноваций и их коммерциализацию. Это позволило определить систему трансформации и определить необходимое для ее нормального функционирования обеспечение. А также определить вектор, который обеспечит устойчивость экономической системы и позволит выстроить национальную инновационную модель развития. На основе предложенной модели оценки эффективности инновационной деятельности страны можно установить, какие именно составляющие являются слабым или, наоборот, сильным местом. Полученная информация служит основанием для определения инновационного концепта развития национальной экономики.

Практическая значимость. Результаты исследования могут быть использованы практиками, учеными, представителями власти для формирования и реализации инновационного концепта развития национальной экономики в государственных программах и стратегиях.

Ключевые слова: инновации, экономическая система, национальная экономика, государственное регулирование

Рекомендовано до публікації докт. екон. наук Т. Г. Вяткіною. Дата надходження рукопису 14.09.17. 